\title{
Differential expression of protein kinase $C$ isoforms in coronary arteries of diabetic mice lacking the G-protein Ga11
}

Dieter Paul Hoyer ${ }^{1}$, Yüksel Korkmaz ${ }^{2}$, Sabine Grönke ${ }^{1}$, Klaus Addicks ${ }^{3}$, Nina Wettschureck ${ }^{4}$, Stefan Offermanns ${ }^{4}$, Hannes Reuter ${ }^{1 *}$

\begin{abstract}
Background: Diabetes mellitus counts as a major risk factor for developing atherosclerosis. The activation of protein kinase C (PKC) is commonly known to take a pivotal part in the pathogenesis of atherosclerosis, though the influence of specific PKC isozymes remains unclear. There is evidence from large clinical trials suggesting excessive neurohumoral stimulation, amongst other pathways leading to PKC activation, as a central mechanism in the pathogenesis of diabetic heart disease. The present study was therefore designed to determine the role of $\mathrm{G}_{\mathrm{q}}$-protein signalling via $\mathrm{G \alpha}_{11}$ in diabetes for the expression of PKC isozymes in the coronary vessels.

Methods: The role of $G \alpha_{11}$ in diabetes was examined in knockout mice with global deletion of $G \alpha_{11}$ compared to wildtype controls. An experimental type 1-diabetes was induced in both groups by injection of streptozotocin. Expression and localization of the PKC isozymes $\alpha, \beta \|, \delta, \varepsilon$, and $\zeta$ was examined by quantitative immunohistochemistry.

Results: 8 weeks after induction of diabetes a diminished expression of PKC $\boldsymbol{\varepsilon}$ was observed in wildtype animals. This alteration was not seen in $G \alpha_{11}$ knockout animals, however, these mice showed a diminished expression of PKC $\zeta$. Direct comparison of wildtype and knockout control animals revealed a diminished expression of PKC $\delta$ and $\varepsilon$ in $\mathrm{G \alpha}_{11}$ knockout animals.

Conclusion: The present study shows that expression of the nPKCS $\delta$ and $\boldsymbol{\varepsilon}$ in coronary vessels is under control of the g-protein $G \alpha_{11}$. The reduced expression of PKC $\zeta$ that we observed in coronary arteries from $G \alpha_{11}$-knockout mice compared to wildtype controls upon induction of diabetes could reduce apoptosis and promote plaque stability. These findings suggest a mechanism that may in part underlie the therapeutic benefit of RAS inhibition on cardiovascular endpoints in diabetic patients.
\end{abstract}

\section{Background}

Diabetes mellitus is a major risk factor for developing coronary artery disease. In the diabetic population atherosclerosis accounts for $80 \%$ of all deaths compared to one third in the general population. Numerous studies have addressed the complex pathogenesis of coronary artery disease. It is assumed that distinct stages can be defined in the progression of the disease. These contain the monocyte and endothelium mediated oxidation of

\footnotetext{
* Correspondence: Hannes.Reuter@uk-koeln.de

'Department of Internal Medicine III, University of Cologne, Kerpener Str. 62, 50937 Cologne, Germany

Full list of author information is available at the end of the article
}

LDL (oxLDL), the monocyte recruitment and extravasation, the formation of foam cells most likely mediated through scavenger receptors followed by inflammatory responses that lead to the building of atherosclerotic plaques, which potentially rupture and lead to myocardial infarction/ischemia.

In a diabetic environment certain mechanisms exist which are incriminated to promote the formation of atherosclerotic lesions. The building of advanced glycation end products (AGEs) which is mainly determined by the level of glucose and time of exposure, the induction of hyperglycaemia induced oxidative stress, hyperglycaemia mediated inflammation through cytokines

\section{Biomed Central}

(c) 2010 Hoyer et al; licensee BioMed Central Ltd. This is an Open Access article distributed under the terms of the Creative Commons Attribution License (http://creativecommons.org/licenses/by/2.0), which permits unrestricted use, distribution, and reproduction in any medium, provided the original work is properly cited. 
including activation of monocytes and adipocytes, the activation of the hexosamine pathway and the regulation of proteinkinase $\mathrm{C}(\mathrm{PKC})$ activity are interacting and engaging in the pathogenesis of atherosclerosis as described above. Numerous operations of these demonstrate a participation of PKC activation. First of all PKC activation increases the pro-oxidant environment by increasing the production of reactive oxygen species in the endothelium [1] supporting the formation of oxLDL. Next the endocytosis of oxLDL can be mediated by scavenger receptors that are controlled by PKC [2]. This oxLDL leads to the release of granulocyte-macrophagecolony-stimulating-factors (GM-CSF) which can be blocked by general PKC blockage [3]. Other factors beside the GM-CSF-release contribute for the monocyte adhesion like the expression of P-selectin that is upregulated by PKC activation [4]. Adhesion of monocytes and accumulation of oxLDL results in the formation of cholesterol loaded foam cells and characteristic atherosclerotic lesions. Typical for the development of more complex lesions is the proliferation and migration of vascular smooth muscle cells (VSMCs) in the subendothelial space which is influenced by different isozymes of PKC [5]. Furthermore the expression of different metallomatrix-proteinases (MMPs), which play a crucial role for the plaque stability and the process of plaque rupture [6], are affected by PKC. So the central role of $\mathrm{PKC}$ in all steps of the formation of atherosclerotic plaques is reflected broadly. In addition, functional examinations show a differential pattern of endothelial barrier properties and therefore the permeability of the endothelium depending on the activation of PKC [7].

PKC is a family of at least twelve isozymes and the particular involvement of the different isozymes is only poorly understood. The family of PKC isozymes is divided in subgroups in order of their enzymatic qualities: The conventional PKCs (cPKC) consist of the isozymes $\alpha, \beta$ and $\gamma$, which are activated in the function of calcium and diacylglycerol (DAG). The new PKCs (nPKC) include the isozymes $\varepsilon, \eta, \delta$, and $\theta$, which are activated independently of calcium but in dependence of DAG. The atypical PKCs (aPKC) $\tau$ and $\zeta$ are activated independently of calcium and DAG. However, the role of PKCs in several important biological processes remains to be elucidated.

In a hyperglycaemic state not only hyperglycaemia per se, but also excessive neurohumoral stimulation are held responsible for the activation of the PKC isozymes $[8,9]$. In cardiac tissue, many of these neurohumoral peptides like angiotensin II, endothelin-1 or noradrenalin, which promote vasoconstriction and oxidative stress, bind to receptors that are coupled to the $\mathrm{G}_{\mathrm{q}}$-protein $\mathrm{G \alpha}_{11}$. Interestingly the blockage of the renin-angiotensin-system (RAS) revealed a significant benefit in controlled randomised studies in a diabetic population $[10,11]$. These clinical observations are supported by animal models in which the blockage of the RAS showed a significantly diminished progression of atherosclerosis [12,13].

Based on these results we generated the hypothesis that a signalling pathway involving the $\mathrm{G}_{\mathrm{q}}$-protein $\mathrm{G \alpha}_{11}$ may substantially mediate the pattern of PKC isoform expression in diabetes and therefore potentially atherogenesis.

To gain further insight in the complex pathological pathways, the present study analyzed the role of $\mathrm{G \alpha}_{11}$ on levels of expression of specific PKC isozymes distribution in the coronary vessels in an early diabetic environment.

\section{Methods \\ Induction and verification of experimental induced STZ-diabetes}

Investigations were carried out with $\mathrm{G \alpha}_{11}$ knockout mice and wildtype mice of the same line (C57/B16). Generation of the knockout mice was described previously [14]. C57BL6 wild type mice were obtained from Charles River Laboratories (Sulzfeld, Germany). The experimental design was approved by proper authorities and controlled by the Animal Welfare Officer of the University of Cologne (certificate AZ 50.203.2-K47,28/ 04). Mice 8 weeks of age were injected intraperitoneally with a single dose of either STZ in $0.1 \mathrm{~mol} / \mathrm{l}$ citrate buffer, pH 4.5 (130 mg/kg), or citrate buffer. 24 hours later, blood glucose levels were determined using a Glucometer (GlucoMen Glycó) and Glucostix (GlucoMen Sensor, A. Menarini Diagnostics) to establish induction of diabetes. Afterwards the blood glucose levels and body weight of mice were monitored weekly. Successful induction of diabetes was defined by a constant blood glucose $>300 \mathrm{mg} / \mathrm{dl}$ over 8 weeks. Throughout the study, animals were housed at $20-22^{\circ} \mathrm{C}$ with fixed $12 \mathrm{~h}$ day/night cycle and given free access to food and water.

\section{Sample Collection and Tissue Preparation}

After 8 weeks of the diabetic status, animals were killed by cervical dislocation. Thoracic cavities were opened and hearts were removed and immersion-fixed using a fixative containing $4 \%$ paraformaldehyde and $0.2 \%$ picric acid in $0.1 \mathrm{M}$ phosphate buffer salt (PBS), $\mathrm{pH} 7.4$ for 24

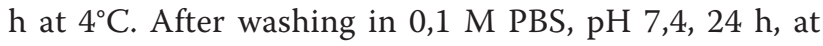
$4^{\circ} \mathrm{C}$, specimen were cryoprotected with $20 \%$ saccharose in $0,1 \mathrm{M}$ PBS, $\mathrm{pH} 7,4,48 \mathrm{~h}$, at $4^{\circ} \mathrm{C}$. Specimen were embedded in tissue-tek and quick-frozen in fluid nitrate. Specimens were cryosectioned with a thickness of $7 \mu \mathrm{m}$ in consecutive sections. The hearts from 6 normal glycemic mice and 6 diabetic mice were presently analyzed in each group. 


\section{Reagents and Antibodies}

The rabbit anti-proteinkinase $C \delta$-monoclonal antibody, the rabbit anti-protein kinase $C \beta I I-$ monoclonal antibody and the rabbit anti-protein kinase $\mathrm{C} \varepsilon$-monoclonal antibody was purchased from Sigma Immunochemicals, St. Louis, MO, USA. The rabbit anti-protein kinase $\mathrm{C}$ $\zeta$-monoclonal antibody and the rabbit anti-protein kinase $\mathrm{C} \alpha$-monoclonal antibody and were purchased from Cell Signaling Technology, Inc., Boston, MA, USA. All other reagents were of analytical grade or the best grade commercially available.

\section{Immunohistochemistry}

In consecutive sections, Avidin-Biotin-Peroxidase Complex Method was performed for the immunohistochemical incubations (Elite ABC Kit, Vector Labor, Peterborough, UK). Endogenous peroxidases were inhibited with $0.3 \%$ $\mathrm{H}_{2} \mathrm{O}_{2}$. To block non-specific bindings, we treated sections with $1 \%$ bovine serum albumin (BSA) $+10 \%$ normal goat serum (NGS). Thereafter, sections were incubated for 24 hrs at $4^{\circ} \mathrm{C}$ with primary monoclonal antibodies against PKC isoforms followed by incubation with biotin-conjugated goat anti-rabbit IgG (1:500) and biotinylated antimouse IgG (1:500), respectively. The sections were then treated with avidin-biotinperoxidase complex (1:100) for $1 \mathrm{hr}$. The reaction was visualized with $0.05 \%$ 3,39-diaminobenzidine tetrahydrochloride (Sigma) in $0.05 \mathrm{M}$ Tris$\mathrm{HCl}$ buffer, $\mathrm{pH} 7.6$, containing $0.01 \% \mathrm{H}_{2} \mathrm{O}_{2}$ and $0.01 \%$ nickel ammonium sulphate. Incubations without the primary or secondary antisera and pre-absorption were carried out as negative controls.

\section{Quantification of Immunohistochemistry}

The densitometric staining intensities of the PKC isoforms in treated and in control sections were measured by image analysis of grey values of immunostaining. The background grey value was measured from four selected regions at a cell free area. The blood vessels grey values were measured from four selected areas of the across sectioned blood vessels wall. Immunostaining intensity was presented as the mean of measured blood vessels grey value minus mean of measured background grey value. For staining intensity detection a Zeiss Axiophot microscope coupled to a 3-chip CCD-camera was used and the analysis was performed using the Optimas 6.00 image analysis program (Imaging Technology Inc., San Diego, CA, USA).

\section{Statistical analysis}

Differences among groups were compared with student's t-test for unpaired observations. The data shown are means \pm SE. The level of significance was set to $\mathrm{P}<0.05$. All $\mathrm{P}$ values reported were based on two-sided tests.

\section{Results}

Induction of STZ-induced experimental diabetes

At the beginning of the study the animals showed no significant difference in the blood glucose levels. For those animals injected with citrate buffer the blood glucose level remained the same for the observed period of 8 weeks. Animals injected with STZ $130 \mathrm{mg} / \mathrm{kg}$ showed a significant increase to $491 \pm 91 \mathrm{mg} / \mathrm{dl}$ in the wildtype group $(\mathrm{P}<0,001)$ and to $432 \pm 107 \mathrm{mg} / \mathrm{dl}$ in the $\mathrm{G} \alpha_{11}$ knockout group $(\mathrm{P}<0,001)$ at the end of the in vivo study (Table 1). Another typical sign of type 1 diabetes beside the catabolic state was an observed polyuria and ketonuria. But the animals fed normally and moved around in their cages freely.

\section{Coronary PKC expression in wildtype and $\mathrm{G} \alpha_{11}$ knockout animals under normoglycaemic conditions}

To evaluate the influence of the g-protein $G \alpha_{11}$ on the coronary expression of the PKC isoforms $\alpha, \beta I I, \delta, \varepsilon$ and $\zeta$, which are known to take crucial part in the pathogenesis of atherosclerosis, we compared wildtype control animals (WT) and $G \alpha_{11}$ knockout control animals (KO) (Figure 1). Conventional PKC isoforms $\alpha$ (PKC $\alpha$ [densitometric Units] WT: $185.02 \pm 32.37$ KO: $267.45 \pm 73.54 ; \mathrm{p}=0.28)$ (Figure 2A vs. Figure 3A) and $\beta \mathrm{II}$ (PKC $\beta \mathrm{II} ; \mathrm{WT}$ : $131.75 \pm$ 41.62; KO: $222.18 \pm 27.04 ; p=0.098$ ) (Figure $2 \mathrm{E}$ vs. Figure $3 \mathrm{E}$ ) were equally expressed in wildtype and knockout animals. The analysis of the nPKC isoforms $\varepsilon$ and $\delta$ both showed a significant attenuation of the expression in coronary vessels in $\mathrm{G \alpha}_{11}$ knockout animals (PKC $\delta$ [densitometric Units] WT: $719.84 \pm 89.32$; KO: $420.00 \pm 58.38$; $\mathrm{p}=0.018$ ) (Figure 2G vs. Figure 3G) (PKC $\varepsilon ; \mathrm{WT}: 671.65$ \pm 81.3; KO: $327.15 \pm 43.64 ; \mathrm{p}=0.0035$ ) (Figure 2I vs. Figure 3I). The atypical PKC isoform $\zeta$ (PKC $\zeta$; WT: 180.48 \pm 99.75; KO: $253.11 \pm 38.45 ; \mathrm{p}=0.48$ ) in turn was similarly expressed in the coronary vessels of wildtype and $\mathrm{G} \alpha_{11}$ knockout animals (Figure $2 \mathrm{C}$ vs. Figure $3 \mathrm{C}$ ).

\section{Coronary PKC expression after 8 weeks of hyperglycaemia} in wildtype and $G \alpha_{11}$ knockout animals

After 8 weeks of diabetes the animals were sacrificed and the coronary vessels were assessed for PKC isoform $\alpha, \beta$ II, $\delta, \varepsilon$ and $\zeta$ expression. First we analyzed the expression of the conventional PKC isoforms (cPKC) $\alpha$ and $\beta \mathrm{II}$ in wildtype animals after 8 weeks of diabetes compared to age matched controls (Figure 2). We detected a low level of PKC $\alpha$ in diabetic animals (DM) and controls (C), which was equivalent (PKC $\alpha$ [densitometric Units] C: $185.02 \pm$ 32.37; DM: $203.23 \pm 37.62 ; \mathrm{p}=0.72$ ) (Figure 2A vs Figure $2 \mathrm{~B})$. PKC $\beta \mathrm{II}$ in the coronary vessels showed only a faint expression with no alteration in the hyperglycaemic state (PKC $\beta$ II [densitometric Units] C: $131.75 \pm 41.62$; DM: $132.42 \pm 20.41 ; \mathrm{p}=0.99$ ) (Figure $2 \mathrm{E}$ vs Figure $2 \mathrm{~F}$ ). We 
Table 1 Bodyweight and blood glucose levels of the animals at the end of the in vivo study

\begin{tabular}{|c|c|c|c|c|}
\hline & $\begin{array}{l}\text { Wildtype Diabetes } \\
n=14\end{array}$ & $\begin{array}{l}\text { Wildtype Control } \\
n=10\end{array}$ & $\begin{array}{l}\mathrm{G} \alpha_{11} \text { Knockout Diabetes } \\
\mathrm{n}=13\end{array}$ & $\begin{array}{l}\mathrm{G} \alpha_{11} \text { Knockout Control } \\
\mathrm{n}=13\end{array}$ \\
\hline Bodyweight (g) & $20.5 \pm 2.6 *$ & $31.6 \pm 2.5$ & $25.2 \pm 3.3 *$ & $32.0 \pm 5.1$ \\
\hline Blood glucose (mg/dl) & $491 \pm 91 *$ & $103 \pm 12$ & $432 \pm 107 *$ & $109 \pm 9$ \\
\hline
\end{tabular}

Data are means \pm plusorminus SEM.

${ }^{*} p<0,05$ vs. Control.

proceeded with examinations of the new PKC isoforms (nPKC) $\varepsilon$ and $\delta .8$ weeks of diabetes did not change the high level of expression of PKC $\delta$ in coronary vessels of wildtype animals (PKC $\delta$ [densitometric Units] C: $719.84 \pm$ 89.32; DM: 640.82 $\pm 76.3 ; \mathrm{p}=0.52$ ) (Figure $2 \mathrm{G}$ vs Figure $2 \mathrm{H}$ ) in contrast to the likewise high level of expression of PKC $\varepsilon$ that was attenuated after 8 weeks of hyperglycaemia (PKC $\varepsilon$ [densitometric Units] C: $671.65 \pm 81.3$; DM: 421.99 $\pm 35.86 ; \mathrm{p}=0.013$ ) (Figure 2I vs Figure 2J). Next we studied the expression of the atypical PKC isoform (aPKC) $\zeta$. This isoform did not show any significant alteration after 8 weeks of diabetes in wildtype animals (PKC $\zeta$ [densitometric Units] C: $180.48 \pm$ 99.75; DM: 217.94 \pm 39.17; p = 0.7) (Figure $2 \mathrm{C}$ vs Figure 2D).

In $G \alpha_{11}$ knockout animals the same examinations were performed comparing the expression of the PKC isoforms $\alpha, \beta \mathrm{II}, \delta, \varepsilon$ and $\zeta$ in coronary vessels after 8 weeks of hyperglycaemia to age matched controls (Figure 3). Again the cPKC isoforms did not show any significant alterations (PKC $\alpha$ [densitometric Units] C: $267.45 \pm 73.54$; DM: $202.62 \pm 36.63 ; \mathrm{p}=0.43$ ) (Figure $3 \mathrm{~A}$ vs Figure $3 \mathrm{~B}$ ) (PKC $\beta$ II; C: $222.18 \pm 27.04 ; \mathrm{DM}: 180.28 \pm 45.17 ; \mathrm{p}=0$,43) (Figure $3 \mathrm{E}$ vs Figure $3 \mathrm{~F}$ ). PKC $\delta$ showed a lower level of expression in the coronary vessels of $G \alpha_{11}$ knockout animals but again like in wildtype animals there was no change of expression detectable after 8 weeks of hyperglycaemia (PKC $\delta$ [densitometric Units] C: $420.00 \pm 58.38$; DM: $412.68 \pm 52.04 ; \mathrm{p}=0.93$ ) (Figure 3G vs Figure 3H). The second nPKC isoform analyzed in this study showed a different pattern of expression in $G_{11}$ knockout animals than in wildtype animals after 8 weeks of diabetes. In $G \alpha_{11}$ knockout animals the expression of PKC $\varepsilon$ was not altered in the coronary vessels after the diabetic period of time (PKC $\varepsilon$ [densitometric Units] C: $327.15 \pm 43.64$; DM: $464.1 \pm 76.79 ; \mathrm{p}=0.13$ ) (Figure 3I vs Figure 3J). Again we proceeded with examination of the aPKC isoform $\zeta$. However PKC $\zeta$ demonstrated a significant decrease in the expression in coronary vessels of $G \alpha_{11}$ knockout mice after 8 weeks of diabetes (PKC $\zeta$ [densitometric Units] C: $253.11 \pm 38.45$; DM: $132.16 \pm 33.8 ; \mathrm{p}=0.042$ ) (Figure $3 \mathrm{C}$ vs Figure 3D) in contrast to wildtype animals.

\section{Discussion}

Diabetes mellitus is a crucial risk factor for developing atherosclerosis. Common agreement exists on the role of excessive neurohumoral stimulation in the pathogenesis of atherosclerotic plaque formation in diabetes, involving angiotensin II and endothelin-1. These hormones bind to

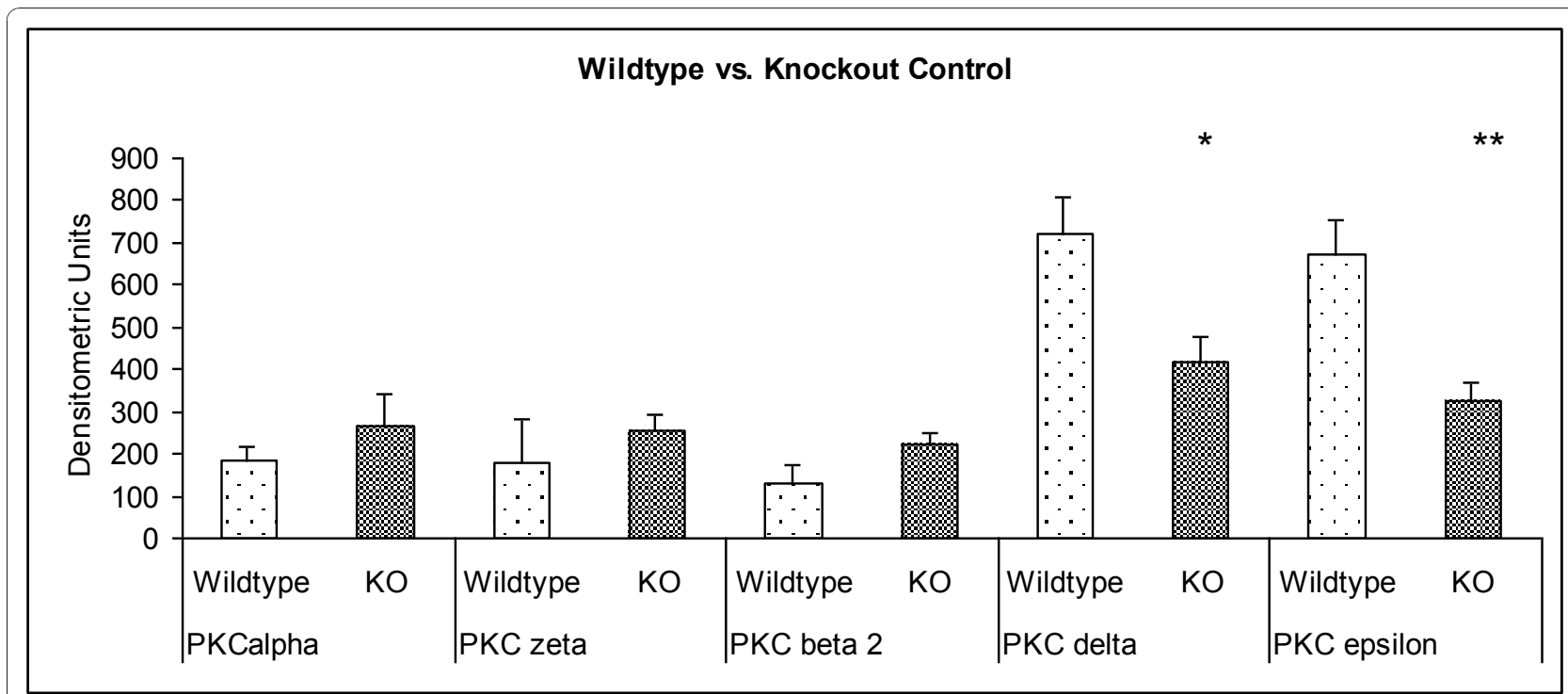

Figure 1 Immunostaining of PKC isozymes in control $G \alpha_{11}$ knockout animals compared to age matched control wildtype animals $\left(G \alpha_{11}\right.$ knockout $\mathbf{n}=6$, wildtype $\left.\mathbf{n}=6\right)$. The $n P K C$ isozymes $\delta$ and $\varepsilon$ showed a diminished expression in $G \alpha_{11}$ knockout animals. KO= Knockout animals. ${ }^{*}=p<0.05$ vs. Control. ${ }^{* *}=p<0.01$ vs. Control. 


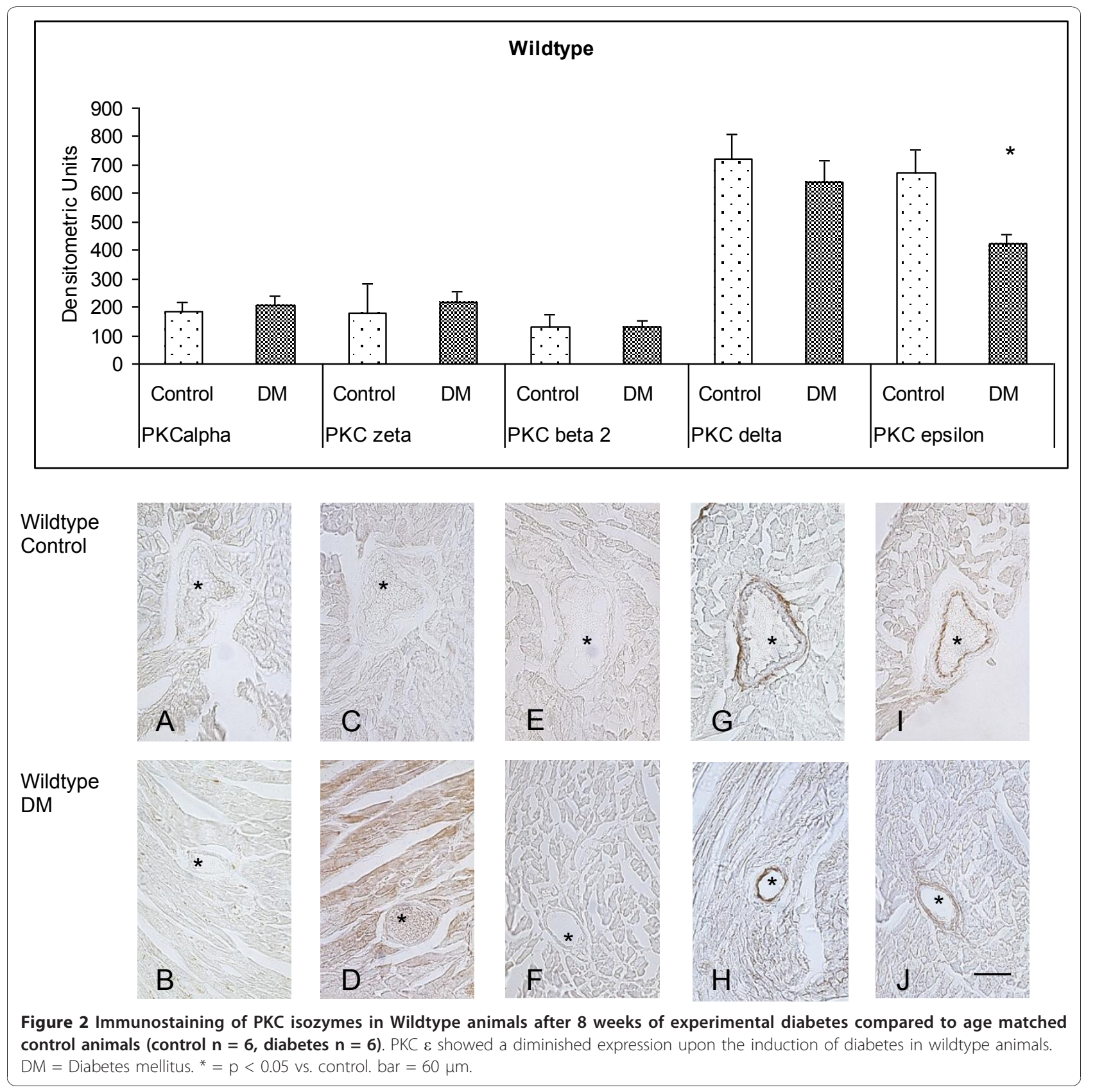

Gq-coupled receptors and may mediate their signal by differential regulation of specific PKC isoforms. Large clinical trials provided evidence of a lower incidence of ischemic heart disease when patients were treated with ACE inhibitors or AT1-receptor blockers compared to other antihypertensive drugs independent of blood pressure control $[10,11]$. These clinical observations are supported by animal models, in which the blockage of the renin angiotensin system (RAS) showed a significantly diminished progression of atherosclerosis [12,13]. The goal of the present study therefore was to gain further insight into the distribution of PKC isozymes in the coronary vessels in a model of an early diabetes mellitus and to define the role of the g-protein $G \alpha_{11}$ on expression and localization of these kinases.

\section{Early diabetes shows no specific regulation of the conventional PKC isoforms $\alpha$ and $\beta$ II}

The conventional PKC isozymes $\alpha$ and $\beta$ II have been shown to take part in different steps of atherogenensis. PKC $\alpha$ appears to be involved in $\mathrm{O}_{2}{ }^{-}$mediated oxidation of LDL serving as a chemotactant for monocytes and may increase phospholipase A2 activation and monocyte platelet endothelial cell adhesion molecule (PECAM-1) 


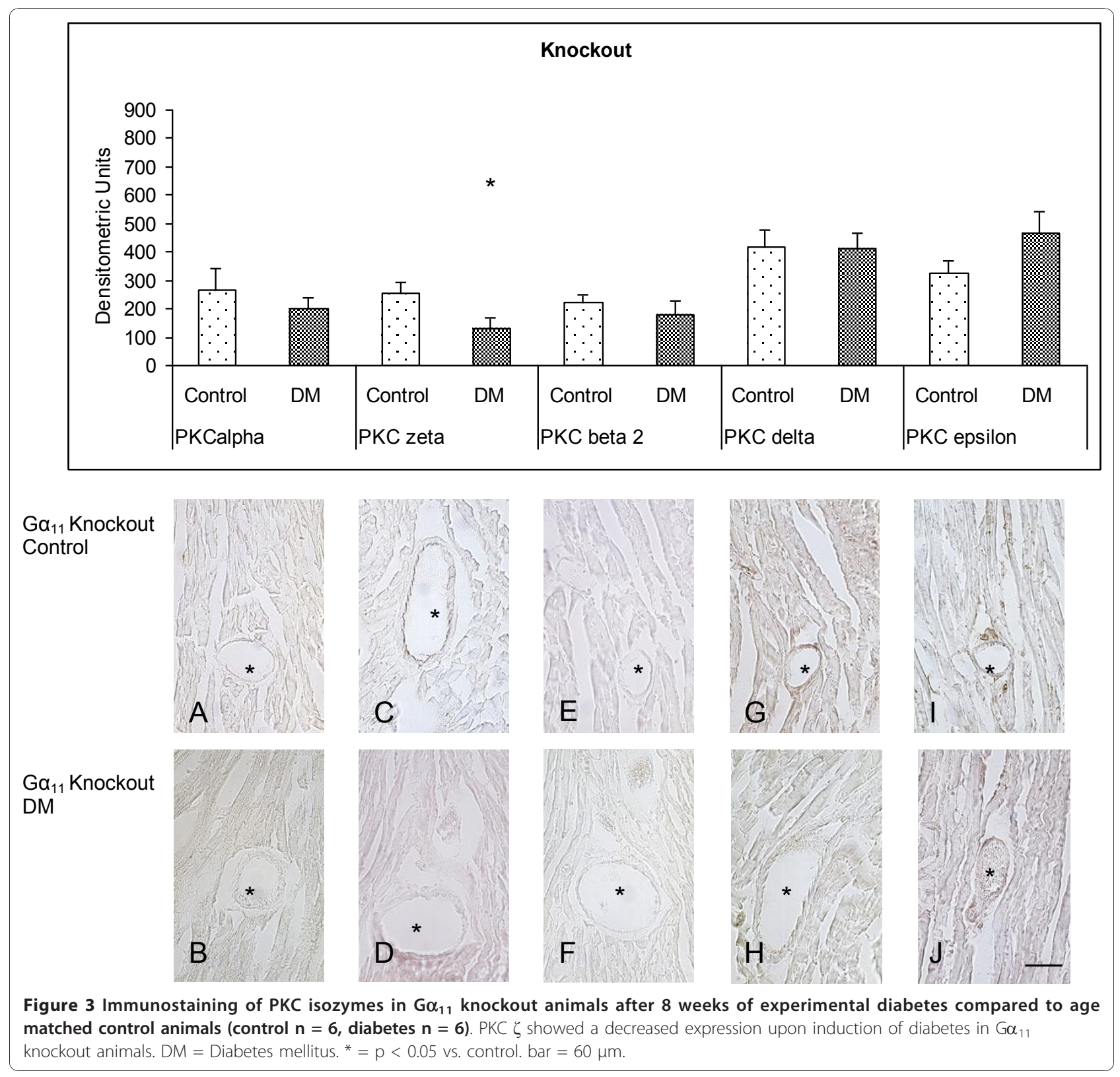

expression, resulting in endothelial adhesion. PKC $\alpha$ has further been shown to stimulate VSMC for translocation and vasoconstriction [15] and to increase MMP-2 expression leading to plaque instability [16]. PKC $\beta$ II appears to be involved in the expression of vascular cell adhesion molecule (VCAM) and inter-cellular adhesion molecule (ICAM) leading to monocyte recruitment and adhesion [17]. In our studies the levels of expression and location of conventional PKC isozymes $\alpha$ and $\beta$ II were unchanged. Hence, in our present study there appears to be no specific regulation of these PKC isoforms in the coronary vessels in early diabetes.
The atypical PKC isoform $\zeta$ is reduced in early diabetes after deletion of $\mathrm{G} \alpha_{11}$

Sorescu and coworkers showed that PKC $\zeta$ can activate the NADPH oxidase supporting the pro-oxidant environment of the atherosclerotic lesion by increasing reactive oxygen species production, thus leading to apoptosis and plaque instability [1]. In addition, the secretion of MMPs can be increased up to 13 -fold through PKC $\zeta$ activity [18] promoting the degradation of extracellular matrix proteins. This pathomechanism has been linked to an increased risk of plaque rupture. In our $G \alpha_{11}$ knockout model protein densities of PKC $\zeta$ were significantly 
diminished after 8 weeks of hyperglycaemia. In light of the current knowledge about the pathogenic role of PKC $\zeta$ in atherosclerosis this reduction in protein densities may thus reflect a protective mechanism in response to the deletion of the g-protein $\mathrm{G \alpha}_{11}$.

\section{Expression of the new PKC isoforms $\delta$ and $\varepsilon$ is under control of $\mathrm{G} \alpha_{11}$}

Compared to wildtype controls, expression of the nPKC isozymes $\delta$ and $\varepsilon$, which are activated independently of calcium but in dependence of DAG, were diminished in $G \alpha_{11}$ knockout animals. This indicates strongly that expression of these isozymes is at least in part regulated by a $G \alpha_{11}$-dependent pathway. Ma and coworkers provided evidence that PKC $\delta$ mediates the accumulation of oxidative LDL (oxLDL) in macrophages [19] leading to the formation of foam cells as one of the major mechanisms in the genesis of atherosclerotic lesions. Furthermore, there is evidence in support of a proapoptotic function of PKC $\delta$ in different cell types including VSMC [20]. In the pathogenesis of atherosclerosis, apoptosis of VSMCs is a central process leading to a marked thinning of the fibrous cap, the loss of collagen and matrix, accumulation of cell debris and intimal inflammation [21]. Following this line of evidence, the lower level of expression of the nPKC $\delta$ that we observed in nondiabetic $G \alpha_{11}$ knockout mice compared to wildtype controls would target several processes that are crucial for atherosclerotic plaque formation. Hence, the $G \alpha_{11}$-dependent reduction in PKC $\delta$ expression could provide a protective mechanism in atherosclerotic heart disease. This view is supported by the persistent low expression of this isozyme in $\mathrm{G \alpha}_{11}$ knockout mice even after induction of diabetes, one of the primary risk factors for atherosclerosis.

The role of PKC $\varepsilon$ in coronary vessels is not yet fully understood but evidence accumulates for an antiproliferative and antiapoptotic effect on VSMCs. Among others, this was nicely demonstrated by Sasaguri and coworkers showing that $\mathrm{PKC} \varepsilon$ suppresses proliferation of VSMCs by inhibition of the cell cycle at the late G1 phase [22]. In addition activation of PKC $\varepsilon$ has been shown to protect against apoptosis through inhibition of the tumor necrosis factor TNF $\alpha$ and activation of transcriptional factor NF- $\kappa \mathrm{B}$ via phosphorylation of $\mathrm{I} \kappa \mathrm{B}$ kinase [23-25]. Recently, Min and coworkers provided evidence for activation of the PKC/NF- $\kappa \mathrm{B}$ pathway in neonatal rat cardiomyocytes exposed to high glucose further supporting the importance of this pathway in the diabetic heart [26].

It seems that PKC $\varepsilon$ is further linked to raf- 1 kinase activation and the mitogen-activated protein kinase pathway and it has been shown that this isoform mediates the effect of angiotensin II in the proximal tubule of the kidney [27]. In our present study protein levels of PKC $\varepsilon$ were reduced in coronary vessels from wildtype mice 8 weeks after induction of diabetes. Similarly, the reduced expression of this isoform following hyperglycemia has previously been described in myocardial tissue [28,29] and a resulting susceptibility for postischemic damage has been postulated. If expression of the nPKCs $\delta$ and $\varepsilon$ were under control of a $\mathrm{G \alpha}_{11}$-dependent signaling pathway we hypothesized that densities of these proteins would not be influenced by strong stimuli like hyperglycemia. The present results support this hypothesis, however, functional implications that would result from this permanent downregulation and possible mechanisms of compensation by other pathways are not yet fully understood. It is also to be considered that individual PKC isoforms may mutually regulate their activity as part of a concerted process involving a network of signalling cascades [30]. Further studies will be needed to address these functional aspects.

\section{Conclusion}

In conclusion, the present study shows that expression of the $\mathrm{nPKCs} \delta$ and $\varepsilon$ in coronary vessels is under control of the g-protein $G \alpha_{11}$. The reduced expression of PKC $\zeta$ that we observed in coronary arteries from $\mathrm{G \alpha}_{11^{-}}$ knockout mice compared to wildtype controls upon induction of diabetes could reduce apoptosis and promote plaque stability. These findings suggest a mechanism that may in part underlie the therapeutic benefit of RAS inhibition on cardiovascular endpoints in diabetic patients.

\section{Acknowledgements}

Our special thanks go to Thomas M. Wilkie (UT Southwestern Medical Center, Dallas, Texas) for developing the knockout animals. This study was supported by the German Heart Foundation/German Foundation of Heart Research (F/11/07 to H. Reuter).

\section{Author details}

${ }^{1}$ Department of Internal Medicine III, University of Cologne, Kerpener Str. 62, 50937 Cologne, Germany. ${ }^{2}$ Dept. of Operative Dentistry, Periodontics and Endodontics, Heinrich-Heine-University, Düsseldorf, Germany. ${ }^{3}$ Insitute of Anatomy I, University of Cologne, Joseph-Stelzmann Str.9, 50931 Cologne, Germany. ${ }^{4}$ Max-Planck-Intitute for Heart and Lung research, W.G. KerckhoffInstitute, Parkstrasse 1, 61231 Bad Nauheim, Germany.

\section{Authors' contributions}

$\mathrm{DPH}$ and YK carried out the immunohistochemistry and performed the statistical analysis. SG participated in the induction of the experimental Diabetes. KA, NW and SO participated in the design of the study. HR conceived of the study and participated in its design and coordination. All authors read and approved the final manuscript.

\section{Competing interests}

The authors declare that they have no competing interests.

Received: 22 September 2010 Accepted: 29 December 2010 Published: 29 December 2010 


\section{References}

1. Sorescu D, Weiss D, Lassègue B, Clempus RE, Szöcs K, Sorescu GP, Valppu L, Quinn MT, Lambeth JD, Vega JD, et al: Superoxide production and expression of nox family proteins in human atherosclerosis. Circulation 2002, 105:1429-35

2. Nicholson AC, Febbraio M, Han J, Silverstein RL, Hajjar DP: CD36 in atherosclerosis. The role of a class $B$ macrophage scavenger receptor. Annals of the New York Academy of Sciences 2000, 902:128-31, discussion 131-3.

3. Matsumura T, Sakai M, Kobori S, Biwa T, Takemura T, Matsuda H, Hakamata H, Horiuchi S, Shichiri M: Two intracellular signaling pathways for activation of protein kinase $C$ are involved in oxidized low-density lipoprotein-induced macrophage growth. Arteriosclerosis, Thrombosis, and Vascular Biology 1997, 17:3013-20

4. Murohara T, Scalia R, Lefer AM: Lysophosphatidylcholine promotes P-selectin expression in platelets and endothelial cells. Possible involvement of protein kinase $\mathrm{C}$ activation and its inhibition by nitric oxide donors. Circulation Research 1996, 78:780-9.

5. Haller H, Maasch C, Lindschau C, Brachmann M, Buchner K, Luft FC: Intracellular targeting and protein kinase $C$ in vascular smooth muscle cells: specific effects of different membrane-bound receptors. Acta Physiologica Scandinavica 1998, 164:599-609.

6. Galis ZS, Sukhova GK, Lark MW, Libby P: Increased expression of matrix metalloproteinases and matrix degrading activity in vulnerable regions of human atherosclerotic plaques. The Journal of Clinical Investigation 1994, 94:2493-503.

7. Gaudreault N, Perrin RM, Guo M, Clanton CP, Wu MH, Yuan SY: Counter Regulatory Effects of PKC $\beta$ II and PKC $\delta$ on Coronary Endothelial Permeability. Arteriosclerosis, thrombosis, and vascular biology 2008, 28:1527-1533

8. Malhotra A, Reich D, Nakouzi A, Sanghi V, Geenen DL, Buttrick PM: Experimental diabetes is associated with functional activation of protein kinase C epsilon and phosphorylation of troponin I in the heart, which are prevented by angiotensin II receptor blockade. Circ Res 1997, 81:1027-33.

9. Lang U, Vallotton MB: Effects of angiotensin II and of phorbol ester on protein kinase $C$ activity and on prostacyclin production in cultured rat aortic smooth-muscle cells. Biochem J 1989, 259:477-83.

10. Lindholm LH, Ibsen H, Dahlof B, Devereux RB, Beevers $G$, de Faire $U$, Fyhrquist F, Julius S, Kjeldsen SE, Kristiansson K, et al: Cardiovascular morbidity and mortality in patients with diabetes in the Losartan Intervention For Endpoint reduction in hypertension study (LIFE): a randomised trial against atenolol. Lancet 2002, 359:1004-10.

11. Estacio RO, Jeffers BW, Hiatt WR, Biggerstaff SL, Gifford N, Schrier RW: The effect of nisoldipine as compared with enalapril on cardiovascular outcomes in patients with non-insulin-dependent diabetes and hypertension. N Engl J Med 1998, 338:645-52.

12. Strawn WB, Chappell MC, Dean RH, Kivlighn S, Ferrario CM: Inhibition of early atherogenesis by losartan in monkeys with diet-induced hypercholesterolemia. Circulation 2000, 101:1586-93.

13. Hernandez A, Barberi L, Ballerio R, Testini A, Ferioli R, Bolla M, Natali M, Folco G, Catapano AL: Delapril slows the progression of atherosclerosis and maintains endothelial function in cholesterol-fed rabbits Atherosclerosis 1998, 137:71-6.

14. Wettschureck N, Rutten H, Zywietz A, Gehring D, Wilkie TM, Chen J, Chien KR, Offermanns S: Absence of pressure overload induced myocardial hypertrophy after conditional inactivation of Galphaq/ Galpha11 in cardiomyocytes. Nat Med 2001, 7:1236-40.

15. Giardina JB, Tanner DJ, Khalil RA: Oxidized-LDL enhances coronary vasoconstriction by increasing the activity of protein kinase $C$ isoforms alpha and epsilon. Hypertension 2001, 37:561-8.

16. Mountain DJ, Singh M, Menon B, Singh K: Interleukin-1beta increases expression and activity of matrix metalloproteinase-2 in cardiac microvascular endothelial cells: role of PKCalpha/beta1 and MAPKs. Am J Physiol Cell Physiol 2007, 292:C867-75.

17. Kawakami A, Aikawa M, Alcaide P, Luscinskas FW, Libby P, Sacks FM: Apolipoprotein CIII induces expression of vascular cell adhesion molecule-1 in vascular endothelial cells and increases adhesion of monocytic cells. Circulation 2006, 114:681-7.

18. Hussain S, Assender JW, Bond M, Wong L-F, Murphy D, Newby AC: Activation of protein kinase Czeta is essential for cytokine-induced metalloproteinase- $1,-3$, and -9 secretion from rabbit smooth muscle cells and inhibits proliferation. The Journal of Biological Chemistry 2002, 277:27345-52

19. Ma H-T, Lin W-W, Zhao B, Wu W-T, Huang W, Li Y, Jones NL, Kruth HS: Protein kinase $C$ beta and delta isoenzymes mediate cholesterol accumulation in PMA-activated macrophages. Biochemical and Biophysical Research Communications 2006, 349:214-20.

20. Goerke A, Sakai N, Gutjahr E, Schlapkohl WA, Mushinski JF, Haller H, Kolch W, Saito N, Mischak H: Induction of apoptosis by protein kinase C delta is independent of its kinase activity. The Journal of Biological Chemistry 2002, 277:32054-62.

21. Clarke MC, Figg N, Maguire JJ, Davenport AP, Goddard M, Littlewood TD, Bennett MR: Apoptosis of vascular smooth muscle cells induces features of plaque vulnerability in atherosclerosis. Nat Med 2006, 12:1075-80.

22. Sasaguri T, Kosaka C, Hirata M, Masuda J, Shimokado K, Fujishima M, Ogata J: Protein kinase C-mediated inhibition of vascular smooth muscle cell proliferation: the isoforms that may mediate G1/S inhibition. Exp Cell Res 1993, 208:311-20.

23. Tojima Y, Fujimoto A, Delhase M, Chen Y, Hatakeyama S, Nakayama K, Kaneko $Y$, Nimura $Y$, Motoyama N, Ikeda $K$, et al: NAK is an IkappaB kinaseactivating kinase. Nature 2000, 404:778-82.

24. Mayne GC, Murray AW: Evidence that protein kinase Cepsilon mediates phorbol ester inhibition of calphostin C- and tumor necrosis factoralpha-induced apoptosis in U937 histiocytic lymphoma cells. J Biol Chem 1998, 273:24115-21.

25. Li RC, Ping P, Zhang J, Wead WB, Cao X, Gao J, Zheng Y, Huang S, Han J, Bolli R: PKCepsilon modulates NF-kappaB and AP-1 via mitogenactivated protein kinases in adult rabbit cardiomyocytes. Am J Physiol Heart Circ Physiol 2000, 279:H1679-89.

26. Min W, Bin ZW, Quan ZB, Hui ZJ, Sheng FG: The signal transduction pathway of PKC/NF-kappa B/c-fos may be involved in the influence of high glucose on the cardiomyocytes of neonatal rats. Cardiovasc Diabetol 2009, 8:8.

27. Karim Z, Defontaine N, Paillard M, Poggioli J: Protein kinase C isoforms in rat kidney proximal tubule: acute effect of angiotensin II. Am J Physiol 1995, 269:C134-40

28. Kang N, Alexander G, Park JK, Maasch C, Buchwalow I, Luft FC, Haller H: Differential expression of protein kinase $C$ isoforms in streptozotocininduced diabetic rats. Kidney Int 1999, 56:1737-50.

29. Jiang J, Yuen $\mathrm{V}$, Xiang $\mathrm{H}, \mathrm{McN}$ eill $\mathrm{JH}$ : Improvement in cardiac function of diabetic rats by bosentan is not associated with changes in the activation of PKC isoforms. Mol Cell Biochem 2006, 282:177-85.

30. Pass JM, Gao J, Jones WK, Wead WB, Wu X, Zhang J, Baines CP, Bolli R, Zheng YT, Joshua IG, et al: Enhanced PKC beta II translocation and PKC beta II-RACK1 interactions in PKC epsilon-induced heart failure: a role for RACK1. Am J Physiol Heart Circ Physiol 2001, 281:H2500-10.

doi:10.1186/1475-2840-9-93

Cite this article as: Hoyer et al:: Differential expression of protein kinase $\mathrm{C}$ isoforms in coronary arteries of diabetic mice lacking the G-protein Ga11. Cardiovascular Diabetology 2010 9:93.

\section{Submit your next manuscript to BioMed Central and take full advantage of:}

- Convenient online submission

- Thorough peer review

- No space constraints or color figure charges

- Immediate publication on acceptance

- Inclusion in PubMed, CAS, Scopus and Google Scholar

- Research which is freely available for redistribution 